Comparative Philosophy Volume 12, No. 2 (2021): 134-146

Open Access / ISSN 2151-6014 / www.comparativephilosophy.org

https://doi.org/10.31979/2151-6014(2021).120210

CONSTRUCTIVE-ENGAGEMENT DIALOGUE:

THE PHILOSOPHICAL ISSUE OF TRUTH

AUTHOR MEETS CRITIC:

\title{
TRUTH IN CHINESE PHILOSOPHY: A COMMENTARY ON BO MOU'S SEMANTIC-TRUTH APPROACHES IN CHINESE PHILOSOPHY
}

\section{CHENYANG LI}

Studies of Chinese philosophy have been overwhelmingly on ethics and social philosophy. Bo Mou's book is significant because it is squarely on semantic truth, a topic which has seldomly been brought up in studying Chinese philosophy (Mou 2019). That alone makes his book worthy of our attention. Mou's book contains many insights and breaks new grounds for further study. His pluralist account of semantic truth in Chinese philosophy is highly original and pioneering in the field. Here I will not attempt to make a comprehensive review or assessment of this important book. Instead, I focus on two points, for the sake of further explorations on the topic. The first is on the general topic of truth in Chinese philosophy. While I do not deny that there is semantic truth in Chinese philosophy, I believe the main orientation of Chinese philosophy on truth is pragmatic, in that the concept of truth is understood and functions in the context of the human condition; the nature and the value of truth lies with its service for the good life. Second, I will offer an alternative to Bo Mou's characterization of Xun Zi's concept of truth and show why Mou cannot dismiss a broadly characterized pragmatic interpretation of Xun Zi's epistemology. In this commentary, I will try to quote Mou's relevant passages in their entirety to ensure as much accuracy as possible in presenting his argument.

1.

In the first chapter of his book, Mou surveys the landscape of various interpretations of truth in Chinese philosophy and divides them into two camps. The first camp holds the

LI, CHENYANG: Professor of Philosophy, Nanyang Technological University, Singapore.

Email: CYLI@ntu.edu.sg 
negative thesis of no-truth-concern in Chinese philosophy, or "NTCP" for short. This is the view that "There is no significant concern with truth (as capturing the way things are) in Chinese philosophy." (Mou 2019, 25) One such representative is Chad Hansen (1985). Hansen is known for his assertion that "Chinese philosophy has no concept of truth." (Hansen 1985, 492) The other camp holds a positive thesis on the concept of truth in Chinese philosophy. Mou further divides the latter into four variations. He labels the first as "truth-as-pragmatic-notion." This is the view that Chinese philosophy has developed a pragmatic concept of truth. Although some views appear as semantic, they are nevertheless pragmatic in essence. The second account is "truth-as-propertyof-persons." On this view, truth is a property of persons. Mou quotes Huston Smith's view of three kinds of notions of truth in India, East Asia, and the West: "India tied truth to things, East Asia to persons, and the West to statement." (Mou 2019, 26) I understand this to mean that, on such an account, a person can be truthful or possess truth or be the opposite. When we inquire truth, we look at persons to see whether they are truthful or not. The third view is of "truth-as-what-really-is," to which I will return shortly. The fourth and last variation in the positive camp is "truth-as-coherence-notion." The fourth view is concerned with the status and nature of moral truth; moral truth lies in being relative, or coherent with, different fundamental local moral ideals and values. Mou regards this view as "a kind of relativist coherence truth account" and identifies David Wong as a representative of this variant. (Mou 2019, 27)

Mou is squarely opposed to the view that there is no significant concern with truth in Chinese philosophy. He argues, such a negative view may imply one of three things. First, since a concern with truth is an identifying characteristic of philosophy, if what we call "Chinese philosophy" is not concerned with truth, it means that "Chinese philosophy" is not real philosophy. Mou rejects such a possible outcome. Another implication is that the concern for truth in philosophy is a regional rather than global matter; whereas Western philosophy is concerned with truth, Chinese philosophy is not. Mou is positively opposed to such a view as his entire project aims to refute it. There is a third possibility. That is, the current Western understanding, identification and formulation of the philosophical concern with truth is seriously limited, and consequently, it has overlooked some distinct approaches, like those in Chinese philosophy. Mou's task is to present these alternative approaches and to bring them into serious discussion in the current philosophical discourse on truth.

Broadly speaking, the four variations of views in the "positive" camp in answering the question of Chinese notion of truth all call for Mou's third possibility. All these four views are grounded on the idea that there are alternatives to mainstream Western conceptions of truth and that Chinese philosophy contains such a viable alternative. Mou's attitude towards these four views, however, is mixed. On the one hand, he thinks that some of these accounts can contribute to our understanding of truth. On the other, he detects a truth-denying element in these accounts and disagrees with their "revisionist" attitude towards people's pre-theoretic "way-things-are-capturing" understanding. I take his view to be that these accounts, "positive" as they are, nevertheless deny Chinese philosophy of its truth element that can be identified with mainstream Western epistemological theories. In other words, Mou advances a stronger 
claim, that Chinese philosophy also contains notions of truth that would be accepted as authentic in mainstream Western philosophy, such as semantic truth.

I have not studied notions of truth in various Chinese philosophers as extensively as Mou has, and I am not as qualified to make general statements about his argument on each thinker that has been included in his rich book. Here I would like to add some clarity to the third "positive" view, that of "truth-as-what-really-is," which Mou attributes to me. He writes,

For example, Chenyang Li endorses this variant and takes truth as "a state of being itself" or as "existence with the highest value and ultimate meaning." Li seems to share with Smith the same idea of multiple truth, but locates "truth-as-what-really-is" in a different way. Smith distinguishes the ontological notion of truth as a property of things from the existential notion of truth as a property of persons and attributes the former to India and the latter to China, while Li seems to merge what Smith calls "the ontological notion of truth" and "the existential notion of truth" into one notion, the "metaphysical" notion of truth as "existence with the highest value and ultimate meaning," and attributes its concern to China as well as India. (Mou 2019, 26-7)

Mou's presentation of the third view is brief due to limited space and it may be subject to different interpretations. I also argue for this "third" account of truth in Chinese philosophy (I am not concerned with truth in Indian philosophy), as an alternative to Mou's account of the Chinese account of truth. I label such an account as "truth as a way of being," rather than "truth-as-what-really-is" as labelled by Mou in his enumeration of the four accounts in the positive camp. Because Mou's description of my account is rather sketchy, I will take a bit of space to explain it first. My account takes into consideration these observations:

(1) In ancient China, philosophy was not divided into subareas such as metaphysics and epistemology, as in modern philosophy. Truth-related matters were studied as an aspect of philosophy rather than a subarea of philosophy. I define their difference as that, relatively speaking, a subarea can be studied independently of other subareas (as one can study logic or epistemology without studying ethics) whereas an aspect has to be studied along with other aspects of the whole subject area.

(2) The primary concern of ancient Chinese philosophy was on how to live a good life and how to establish a good society. Consequently, truth-related matters were considered in close connections to this central theme and aimed to address questions connected to this primary concern.

(3) There was not a single term for truth in ancient Chinese philosophy. This phenomenon can be explained by the observations in (1) and (2).

(4) When terms were used in discussing truth-related matters as well as other aspect(s) of philosophy, it is likely that these have been connected in ancient thinkers' overall philosophical conceptualizations.

We can read the above as an inductive argument with (4) as the conclusion that is supported by the three preceding statements. The argument does not imply that there is not semantic truth in ancient Chinese philosophy; it does suggest, however, that our interpretations of its semantic truth should be formulated in the context of ancient 
thinkers' primary concerns and that semantic truth is likely to have been subsumed in their primary concerns, even though not totally overlooked.

On the basis of the above observations, my account of the conception of truth in ancient Chinese philosophy can be roughly summarized as follows: ${ }^{1}$

The primary concern of ancient Chinese thinkers was how to live a good life. As an indispensable aspect of their conceptions of the good life, matters related to truth are explored and construed primarily in terms of what truth-related matters contribute to the good life. Truth, consequently, is a matter of how a person understands things in the world and how one acts appropriately in conducting one's life. Acting appropriately is a way of being. Truth is about being-true in living in the world.

Let us take Confucianism as an example. The closest concept to truth in Confucian philosophy is probably "cheng 诚." In Confucian philosophy, cheng has various meanings. ${ }^{2}$ One of these meanings is trueness or truth. In this sense, to be cheng means being true to oneself, to other people, and to the world. Being true is a matter of truth. This meaning encompasses sincerity (i.e., being sincere) as it is often interpreted, but it is framed on the ontological ground of being. When understood as a person's internal state, sincerity is not purely a mental property; it is also a way of one's being who she is and what she is. In this sense cheng suggests authenticity. A sincere person is a true or truthful and authentic person.

D.C. Lau is one of the influential scholars who have interpreted cheng as "true." For instance, Mencius 4A12 states:

反身不诚, 不悦于亲矣; 诚身有道: 不明乎善, 不诚其身矣。是故诚者, 天之道也; 思诚者, 人之道也。至诚而不动者, 未之有也; 不诚, 未有能动者也。

Lau translated the passage as follows:

If upon looking within he finds that he has not been true to himself, he will not please his parents. There is a way for him to become true to himself. If he does not understand goodness he cannot be true to himself. Hence being true is the Way of Heaven; to reflect upon this is the Way of man. There has never been a man totally true to himself who fails to move others. On the other hand, one who is not true to himself can never hope to move others. (Lau 1976, 123)

On reading this passage, one may wonder whether it is accurate that "there has never been a man totally true to himself who fails to move others." However, it would be less of a concern if we understand this passage as aiming to persuade people to be true to themselves rather than making a semantic claim about the statement itself.

\footnotetext{
${ }^{1}$ For detailed account, please see Li 1999, Chapter 2, "Truth."

${ }^{2}$ For various meanings of cheng, readers can see Li 2018.
} 
"Being true" is key to Lau's understanding of cheng. Being true is a way of being for the person.

But, how does this have to do with true knowledge? I argue that such a notion bears on true knowledge as an extension to a person's true-being. The Yi-Jing's Wenyan Commentary extends cheng explicitly to the use of language. It states that the jun-zi establishes his truthfulness into his deliberate words (xiu-ci-li-qi-cheng 修辞立其诚). Although the statement itself is about written words, it can be extended to the use of language in general. The statement means that one should live a truthful life by saying (writing) trustworthy words. Commenting on the Cheng Brothers' interpretations of this statement, Zhu Xi said,

Cheng Yi interprets "xiu-ci-li-cheng" as to "carefully choose one's words and be truthful to one's determination." His is a broad reading. Cheng Hao has a better account: using deliberate words is about establishing one's sincere determination. It means to embody his belief in the real affair of "acting respectfully in order to maintain the internal upright and rightfully in order to keep the external fair."3 (Zhu, vol.5, 1718)

It is noteworthy that the way Zhu Xi characterizes Cheng Hao's belief in his moral principle as a belief in the real affair (shi-shi 实事), which can also be translated simply as fact. This suggests that Zhu Xi takes Cheng Hao to hold moral principles as facts, a part of reality. It makes sense in Zhu's philosophical system of $l i$ (理), namely objective principles of things in reality. Hence, the trustworthiness of one's words (li-cheng) lies in saying trustworthy words, but it also implies that one's words and action should reflect reality. Zhu elaborates,

The Qian hexagram section of the Yi-Jing states,

Junzi advance virtue and establish good deeds. They are dedicated and trustworthy so they advance virtue. They xiu-ci-li-cheng so they have their good deed to live on."4

Zhu Xi elaborates the above statement as following:

"Dedication and trustworthiness" mean the same as cheng in the statement that "upon looking at oneself and finding cheng" the Zhong-Yong and the Mencius. It is about to know the real and to act on it... "Dedication and trustworthiness" imply to know the ultimate truth in reality. "Xiu-ci-li-cheng" means to act on the ultimate truth in reality. If you do not know the true reality, how can you advance? ${ }^{5}$

\footnotetext{
3伊川解“修辞立诚”作“择言笃志”, 说得来宽。不如明道说云：“修其言辞, 正为立已之诚意。” 乃是体当自家“敬以直内, 义以方外”之实事. (Zhu, vol.5, 1718) All quotes of Chinese texts in this essay are searchable at https://ctext.org/.

4 君子进德修业。忠信所以进德，修辞立诚所以居业.

5 这“忠信”二字, 正是中庸之“反诸身而诚”, 孟子之“反身而诚”样“诚”字。是知得真实了, 知得决 然是如此... “忠信” 是知得到那真实极至处, “修辞立诚” 是做到真实极至处。若不是真实知得, 进个甚么?
} 
We should note that here $\mathrm{Zhu} \mathrm{Xi}$ extends the notion of xiu-ci-li-cheng in the Yi-Jing into a philosophy that connects ethics and epistemology. On the one hand, it is about acting in the right way in real life. On the other, it presupposes knowledge about reality. Such a notion of knowledge includes an idea of truth. On his account, without true knowledge, one cannot act in a moral way. Zhu Xi emphasizes,

If it is dark ahead, how can you move forward? Once you know the truth in reality, yet you do not act on it, then you leave this reasoning hanging in mid-air without a solid ground. ${ }^{6}$

For $\mathrm{Zhu} \mathrm{Xi}$, the ultimate purpose of all these is action rather than mere knowledge. One cannot act well without knowledge. Merely knowing things without acting on the knowledge is incomplete knowledge. Acting is a way of being. In responding to an inquiry about the Yi-Jing statements of “zhi-zhi zhi-zhi 知至至之” and “zhi-zhong zhong-zhi 知终终之," Zhu Xi says,

Knowing the ultimate (zhi-zhi) and achieving the ultimate knowledge (zhi-zhong) both are about knowing affairs (in the world). Reaching the ultimate and ending at the ultimate are both about resolutely acting on these affairs. ${ }^{7}$

For Zhu Xi, we definitely should know what is going on in the world. Our words must reflect the world's actual affairs. However, we do not do so for the sake of epistemic reasons alone; we do it for the sake of moral action. Ultimately, it is for the good life that we pursue in the world.

In such a view, epistemological considerations are extensions of moral philosophy. Truth and the knowledge of truth are ways of being, namely being a good person. This is what I mean by the expression of "truth as a way of being." On this account, not knowing the truth or true affairs in the world prevents people from acting on the truth and from pursuing a truthful life. The truth of statements consists in their being used to reveal ways of being in the world, both for persons and nonhuman objects. ${ }^{8}$

2.

Now let us take a look at Xun Zi's view of truth, truth-related matters and how Xun Zi's view is aligned with the above outlined Confucian view of truth.

As I understand it, Mou interprets Xun Zi's view of morality and truth largely as follows:

(1) Xun Zi's concern about truth plays a vital role in his moral philosophy. (Mou 2019, 165)

\footnotetext{
6 前头黑淬淬地, 如何地进得去? 既知得, 若不真实去做, 那个道理也只悬空在这里, 无个安 泊处; 所谓“忠信”, 也只是虚底道理而已。

7 问: “ “知至至之'致知也; “知终终之’力行也。”虽是如此, 知至、知终皆致知事, 至之、终之 皆力行事。The phrases 'zhi-zhi zhi-zhi 知至至之' and 'zhi-zhong zhong-zhi 知终终之' in the Yi-Jing are subject to different interpretations. Presented here is Zhu Xi's interpretation.

${ }^{8}$ For more discussion of this characterization of truth in Chinese philosophy, readers can see Li 2018.
} 
(2) The basis and foundation of human morality lies with tian or tian-ming as the fundamental principle of the natural world. In other words, the truth of human normative morality lies fundamentally in capturing the way tian-ming (as the fundamental principle of the natural world) is. (Mou 2019, 166)

(3) Tian-ming as the fundamental principle of the natural world constitutes the basis of human morality through shi 实 (actuality). (Mou 2019, 169)

(4) Shi 实 (actuality) provides the metaphysical basis for unifying the fundamental principle of the world on the one hand and human moral activities that follow the fundamental principle on the other. And in practice, shi is captured by the rectification of names. (Mou 2019, 170)

I have some questions about Mou's articulation. First, I do not believe that "tianming" is such an important concept in Xun $\mathrm{Zi}$ as Mou has made it appear to be. The compound term "tian-ming" appears only once in the entire $X u n-Z i$, in the passage that Mou cites,

One's having good command [well capturing, understanding and following the point] of the Heaven's fundamental principle for the sake of [smoothly] abiding by it....Adapting oneself to [dynamic manifestation of] the Heaven's fundamental principle for the sake of [smoothly] following it. (制天命而用之,...应时而使之) (Mou 2019, 168)

Among others, the Chinese word "ming" carries the meaning of the English "order" in the double sense of "command" and "proper alignment" (as implied in the description of "orderly") with the latter including natural order, human-made order, or destined order. We find both meanings in the Xun-Zi. One can obey someone's ming, as in "cong-ming" (从命, in Chapters Chen-Dao, Zi-Dao) or disobey, as in "ni-ming" (逆命, Chapter Chen-Dao). In the latter sense, Xun Zi says that life or death is a matter of ming (死生者, 命也; Chapter You-Zuo). If tian-ming had been an important concept in the Xun-Zi, one would expect it to occur more than once in the book. Since the compound term appears only once, it is probably a one-time combination of the two words to connect their meanings. That is, tian-ming means the ming of tian. Within the context in which the compound term is used, it should mean the natural order of tian, namely the order with which tian operates. Let me quote the entire passage where the term tian-ming occurs:

To exalt Heaven and long for it- How can this compare to nourishing things and overseeing them? To obey Heaven and praise it - How can this compare to overseeing what Heaven has mandated [tian-ming] and using it? To observe the seasons and wait upon them- How can this compare to responding to the seasons and employing them? To follow along with things and increase them- How can this compare to developing their powers and transforming them? To long for things and appraise them- How can this compare to ordering things and never losing them? To desire that from which things ariseHow can this compare to taking hold of that by which things are completed? Thus, if one 
rejects what lies with man and instead longs for what lies with Heaven, then one will have lost grasp of the disposition of the myriad things. ${ }^{9}$ (Hutton 2014, 180-1)

Tian-ming, translated as "what Heaven has mandated" here, is the natural order of tian, as manifested in its routine operation. To make use of it, as in responding to the seasons in human activities, requires us to know how it operates; there is an epistemic aspect to this idea. However, Xun Zi's tian does not have moral meaning in itself, nor is it any fundamental principle that dictates morality. The orderly operation of tian continues regardless of whether humans are acting morally (as in the case of King Yao) or immorally (as in the case of King Jie).

Xun $\mathrm{Zi}$ emphasizes the need to distinguish the operation of tian from handling human affairs. Xun Zi states,

There is a constancy to the activities of Heaven. They do not persist because of Yao [a sage king]. They do not perish because of Jie [an evil tyrant]. If you respond to them with order, then you will have good fortune. If you respond to them with chaos, then you will have misfortune. If you strengthen the fundamental works and moderate expenditures, then Heaven cannot make you poor. If your means of nurture are prepared and your actions are timely, then Heaven cannot make you ill. If you cultivate the Way and do not deviate from it, then Heaven cannot ruin you. Thus, floods and drought cannot make you go hungry or thirsty, cold and heat cannot make you sick, and aberrations and anomalies cannot make you misfortunate.

He continues,

To receive the benefits of the seasons is the same as having an ordered age, but calamities and disasters are incompatible with there being an ordered age. You must not complain against Heaven; its way is simply thus. And so, one who understands clearly the respective allotments of Heaven and humankind can be called a person of utmost achievement. ${ }^{10}$ (Hutton 2014, 175)

Where Hutton translates as to "understand clearly the respective allotments of Heaven and humankind” (明于天人之分), Mou interprets as follows:

One needs to distinguish two kinds of human affairs, the Heaven's fundamental-principlecapturing/following ones and the Heaven's fundamental-principle-violating ones; one thus

\footnotetext{
${ }^{9}$ 大天而思之, 孰与物畜而制之! 从天而颂之, 孰与制天命而用之! 望时而待之, 孰与应时而 使之! 因物而多之, 孰与骋能而化之! 思物而物之, 孰与理物而勿失之也! 愿于物之所以生, 孰与有物之所以成! 故错人而思天, 则失万物之情。

10 天行有常, 不为尧存, 不为然亡。应之以治则吉, 应之以乱则凶。强本而节用, 则天不能贫; 养备而动时, 则天不能病; 修道而不㲴, 则天不能祸。故水旱不能使之饥, 寒暑不能使之疾, 祅怪不能使之凶。本荒而用侈, 则天不能使之富; 养略而动罕, 则天不能使之全; 倍道而妄行, 则天不能使之吉。故水旱未至而饥, 寒暑未薄而疾, 祅怪未至而凶。受时与治世同, 而殊祸与 治世异, 不可以怨天, 其道然也。故明于天人之分, 则可谓至人矣。
} 
realizes that one can have good command of understanding Heaven's fundamental principle and adapt oneself to it so as to smoothly abiding by it. (Mou 2019, 168)

It seems that Mou is saying that the need to distinguish (fen 分) here is about the distinction between two kinds of human activities, namely activities that capture/follow Heaven's fundamental principle and activities that violate this principle. Such a reading is inconsistent with what Xun $\mathrm{Zi}$ elaborates immediately after he advocates his distinction:

That which is accomplished without anyone's doing it and which is obtained without anyone's seeking it is called the work of Heaven. With respect to what is like this, even though he thinks deeply, a proper person does not try to ponder it. Even though he is mighty, he does not try to augment it by his own abilities. Even though he is expertly refined, he does not try to make it more keenly honed. This is called not competing with Heaven's work. (Hutton 2014, 175)

Therefore, the distinction is about being clear of setting apart the role of humankind from the role of Heaven, rather than the two kinds of activities of either following or violating Heaven's way. Xun Zi maintains that Heaven has its proper seasons, Earth has its proper resources, and humankind has its proper order. When they each perform their own respective roles, they form a triad. (Hutton 2014, 176)

Mou seems to have taken actuality in the metaphysical sense as the foundation of Xun Zi's moral philosophy. Mou writes,

For Xun $\mathrm{Zi}$, it is shi (实 actuality) that constitutes the general metaphysical basis and thus conceptual foundation of unifying the relationship between tian (Heaven or Nature as the natural world) via tian-ming as the fundamental principle of the natural world, on the one hand, and the Heaven's fundamental-principle-capturing/following human affairs via human morality in the moral world, on the other, and between tian and people's understanding of nonhuman affairs in the nonmoral world: tian (Heaven or Nature as the natural world) via tian-ming as the fundamental principle of the natural world is shi that is supposed to be captured and pursued by people's understanding of both human (moral and political) affairs and nonhuman affairs in the same natural world. (Mou 2019, 170)

On Mou's interpretation, Xun Zi's notion of the natural order of the world has moral implications. People are moral when their activities capture/follow the natural order of the world; they are immoral when their activities violate the natural order of the world.

I read Xun Zi's view differently. In my opinion, Xun Zi's natural order does not have directly any moral implications. As Xun Zi says, the constancy of tian's operation activities is indifferent to human behavior. It does not persist because of a sage king, nor does it perish because of an evil despot. One is a sage king not because he follows the natural order to tian, nor one an evil tyrant because he fails to follow the natural order of tian. It is how they treat the people that determines their moral standing. Human morality is simply not established on the operation of tian. 
If so, how should we understand the nature of human morality in Xun Zi? What is the role of shi (actuality) in Xun Zi's moral philosophy? And how does shi connect to tian? Xun Zi's moral philosophy is naturalist, but not realist, in the sense I use these labels. By "naturalist" I mean a moral theory without a supernatural foundation. By "realist" I mean the view that morality is about following objective moral principles that are embedded in the world. I take Xun Zi's moral philosophy as naturalist because it does not rely on a divine power or other supernatural force. His moral philosophy is not realist because it is not established on a logically prior metaphysical basis. The starting point of Xun Zi's moral philosophy is the welfare of humanity. He thinks that uncontrolled human desires will cause contention among people for limited resources. Such an assessment calls for the institution of human society and the regulation of people's social lives. Therefore, we need to establish ritual propriety ( $l i$ 礼) in order to regulate social interactions. This should not be understood merely as suppressing human desires. In fact, Xun Zi suggests that human desires can grow. ${ }^{11}$ One important aspect of ritualized regulation is the proper use of names. In a good society people use names correctly in denoting appropriate objects. The objects that Xun $\mathrm{Zi}$ is concerned with are first of all people's appropriate social roles. In this regard, Xun Zi is quite consistent with Confucius, who insists on jun-jun, chen-chen, $f u-f u, z i-z i$ (君君, 臣臣, 父父, 子子, that a king should be like a king, a minister should be like a minister, a father should be like a father, and a son should be like a son). Xun Zi writes,

When different forms make contact with the heart, they make each other understood as different things. If the names and their corresponding objects [shi] are tied together in a confused fashion, then the distinction between noble and base will not be clear, and the like and the unlike will not be differentiated. If this is so, then the problem of intentions not being understood will surely happen, and the disaster of affairs being thereby impeded and abandoned will surely occur. Thus, the wise person draws differences and establishes names in order to point out their corresponding objects [shi]. Most importantly, he makes clear the distinction between noble and base, and more generally, he distinguishes the like and the unlike. When noble and base are clearly distinguished, and like and unlike are differentiated, then the problem of intentions not being understood will not happen, and the disaster of affairs being thereby impeded and abandoned will not occur. This is the reason for having names. ${ }^{12}$ (Hutton 2014, 237)

\footnotetext{
11 使欲必不穷乎物, 物必不屈于欲, 兩者相持而长。(Xun-Zi, 19.1) The first two sentences are often interpreted erroneously as saying the same thing, namely, human desires should not exhaust natural resources. This is not correct. In these statements, the expressions of 不穷乎 and 不屈于 are synonymous, whereas their subjects and objects are reversed in order. They cannot possibly say the same thing. His statements say that human desires and natural resources should mutually support each other and grow together. Furthermore, in the context of our discussion on the human relation with nature, we read Xun $\mathrm{Zi}$ as talking primarily about natural resources, even though strictly speaking, resources for Xun Zi were not limited to being "natural." For a full argument on this point, readers can see Li 2021.

12 异形离心交喻, 异物名实玄纽, 贵贱不明, 同异不别; 如是, 则志必有不喻之患, 而事必有 困废之祸。故知者为之分别制名以指实, 上以明贵贱, 下以辨同异。贵贱明, 同异别, 如是则 志无不喻之患, 事无困废之祸, 此所为有名也。
} 
Xun $\mathrm{Zi}$ is explicit that the primary purpose of using names correctly is to distinguish the noble and base in society, to make sure social arrangements truly reflect the shi of people's qualities. To be sure, Xun Zi's concept of shi also includes non-human objects in the world. However, his reason for using names correctly is not for the sake of "truth" per se, i.e., capturing what the reality is, but to avoid bad consequences in society. As Xun $\mathrm{Zi}$ has argued, if we do not use names to denote proper objects, we will not be able to distinguish people in various social stations and we will not be able to communicate effectively with respect to things we speak about. This will cause social chaos and society will collapse. In other words, epistemic truth is not the primary concern for Xun $\mathrm{Zi}$. It is relevant, as in his discussion of names denoting the appropriate objects, only in so far as it serves our purpose of constructing and maintaining an orderly and harmonious society that is effectively regulated by ritual propriety.

This attitude is extended to Xun Zi's view of the order of the operation of the natural world as well. For Xun Zi, human activities do not affect the operation of the natural world. Nor does the operation of the natural world interfere with human activities. As Xun Zi explicitly states,

For Heaven can give birth to creatures, but it cannot enforce distinctions among creatures. Earth can support people, but it cannot order people. In the world, all members of the myriad things and the human race must await the sage, and only then will they be appropriately divided up. ${ }^{13}$ (Hutton 2014, 210-1)

On Xun Zi's account, a good king or a bad king does not change the order of the natural world; nor does the order of the natural world stop or support a good king or a bad king. However, if we act in accordance with the order of the natural world, we are likely to get the resources we need for society. If we act against it, we are likely or even definitely unable to get the resources we need, which in turn causes problems in society. Thus, in the Chapter on ritual propriety (Li-Lun), Xun Zi writes,

Ritual has three roots. Heaven (tian) and Earth are the root of life. Forefathers and ancestors are the root of one's kind. Lords and teachers are the root of order. Without Heaven and Earth, how would one live? Without forefathers and ancestors, how would one have come forth? Without lords and teachers, how would there be order? If even one of these three roots is neglected, no one will be safe. And so, ritual serves Heaven above and Earth below, it honors forefathers and ancestors, and it exalts lords and teachers. These are the three roots of ritual. ${ }^{14}$ (Hutton 2014, 202).

It is not entirely clear what Xun Zi means by holding that tian is a root of ritual. A direct reading of this passage suggests that $\mathrm{Xun} \mathrm{Zi}$ is saying that tian, together with Earth, provides the conditions for life. Without it, there can be no life, nor society, and

\footnotetext{
13 天能生物，不能辨物也，地能载人，不能治人也; 宇中万物生人之属，待圣人然后分也。

14 礼有三本 : 天地者, 生之本也; 先祖者, 类之本也; 君师者, 治之本也。无天地, 恶生? 无 先祖, 恶出? 无君师, 恶治? 三者偏亡, 焉无安人。故礼、上事天, 下事地, 尊先祖, 而隆君 师。是礼之三本也。
} 
of course nor ritual. Could one read more into it? Could Xun Zi suggest that tian provides not only the environment for human lives, but also the metaphysical basis for ritual as a moral instrument? I think that, even if we grant such an interpretation, we still cannot draw a conclusion that $\mathrm{Xun} \mathrm{Zi}$ is a moral realist, namely that he holds morality is about acting in accordance with the way that tian operates. For Xun Zi, morality has to do with establishing and maintaining social order, and social order depends on sages, not on tian. As Mark Berkson has aptly put,

What is remarkable about Xun Zi's Confucianism-and what separates it from the vast majority of other traditions (including Mengzian Confucianism) - is that it does not assume that there is an underlying order (nomos), a primordial, divinely sanctioned harmony or goodness to the natural world or cosmos. Thus, ritual does not celebrate or sanctify a preexisting, discovered order; ritual itself creates this order even as it sacralizes it. One celebrates not only the order itself but also the ongoing creating and sustaining of it in ritual activity. (Berkson 2014, 126-7)

This point is summarized well in Xun Zi's slogan of "understanding clearly the respective allotments of Heaven and humankind” (明于天人之分).

I hope my above analysis of Xun Zi's moral philosophy and his notion of truth (i.e., correct use of names in denoting objects) can serve as an example of my characterization of ancient Chinese philosophy with regard to truth. As stated at the beginning of this commentary, the primary concern of ancient Chinese philosophy is on how to live a good life and how to establish a good society. Consequently, truthrelated matters were considered in close connections to this central theme and aim to address questions related to this primary concern. This includes Xun Zi's theory of human society, the operation of the natural world, and the correct use of names in society.

In closing, I would like to thank Bo Mou for sharing with us his systematic study of ancient Chinese philosophical ideas of truth. His work gives us much to reflect more deeply than before on how to make sense of ancient Chinese philosophy. In my view, regardless of what ancient Chinese thinkers have envisioned, the contemporary world definitely needs to take epistemology and truth theory more seriously than they were taken over two thousand years ago. Mou's work propels us in the right direction.

\section{ACKNOWLEDGEMENTS}

Research for this paper was supported by a Singapore Ministry of Education grant (\#RG114/20). 


\section{REFERENCES}

Berkson, Mark (2014), "Xun Zi's Reinterpretation of Ritual: A Hermeneutical Defense of the Confucian Way", in Ritual and Religion in the Xunzi, Kline T.C. III and Justin Tiwald (Albany: State University of New York Press), 107-134.

Hutton, Eric L. (2014), Xunzi: The Complete Text (Princeton: Princeton University Press).

Lau, D.C. (1976), Mencius (trans.) (Middlesex, England: Penguin Books).

Li, Chenyang (1999), The Tao Encounters the West: Explorations in Comparative Philosophy (Albany, NY: The State of New York University Press).

Li, Chenyang (2018), "Supplementing Ames on Creativity: A Heideggerian Interpretation of Cheng", in Appreciating the Chinese Difference: Engaging Roger T. Ames on Methods, Issues, and Roles, ed. James Behuniak (Albany, NY: The State University of New York Press), 133-158.

Li, Chenyang (2021), “荀子物欲矢系新解” [“A New Interpretation of the Relation between Material Goods and Desires in Xun-Zi'], forthcoming.

Mou, Bo (2019), Semantic-Truth Approaches in Chinese Philosophy: A Unifying Pluralist Account (New York/London: Lexington Books).

Zhu, Xi 朱喜 (1986), 《朱子語類》[Collected Sayings of Zhu Xi], edited by 黎靖德 LI Jingde (北京 Beijing: 中華書局 Zhong-Hua-Shu-Ju). 